\title{
Publication of Enduring Quality Award
}

We at Land Economics are delighted to announce that the article "The Effect of Agricultural Policy on Farmland Values," by Alfons Weersink, Steve Clark, Calum G. Turvey, and Rakhal Sarker, published in Land Economics volume 75, number 3, pp. 425-39, has won the Canadian Agricultural Economics Society's Publication of Enduring Quality Award.

We reprint the article abstract here:

The extent to which agricultural support programs have been capitalized into farmland prices has been examined in this study. A present value land price model was developed which decomposes returns to the land base into its two possible sources (farm production and government subsidies) and allows the discount rates associated with these two income sources to vary. The empirical results indicate that government payments are discounted less than market-based returns in Ontario. Thus, government payments have been viewed as a more stable source of income to Ontario farm operators during the last half century than market-based returns.

Weersink and Sarker are with the Department of Food, Agricultural, and Resource Economics, University of Guelph; Clark is with the Department of Business and Social Sciences, Dalhousie University; and Turvey is with the Charles H. Dyson School of Applied Economics and Management, Cornell University.

Daniel W. Bromley Editor

Land Economics • November 2014 • 90 (4): iii ISSN 0023-7639: E-ISSN 1543-8325

(C) 2014 by the Board of Regents of the University of Wisconsin System 